\title{
Beberapa Permasalah Penerapan Paten dan Upaya untuk Membangun Sistem Paten Indonesia yang Efektif, Wajar, dan Realistis
}

\section{Syihabuddin}

\begin{abstract}
-
On August 1, 2001 the govemment ratified Law No 142001 conceming Patent in place of the previous Law. In fact, there is nothing wrong with Indonesian Patent Law. Unfortunately, the implementation of such law still face various obstacles. The following article will highlight problems in implementing patent in Indonesia, and efforts to establish an effective, genuine, and realistic patent system.
\end{abstract}

\section{Pendahuluan}

Dalam lima tahunan terakhir, Hak Kekayaan Intelektual (HKI)' -termasuk paten, mengalami perkembangan menonjol dan mendapat perhatian yang sangat besar dari masyarakat Indonesia dan masyarakat dunia. Hal ini disebabkan oleh beberapa hal, antara lain: Pertama, meningkatnya kecepatan penemuan-penemuan di bidang teknologi, antara lain meliputi teknologi elektronik, telekomunikasi dan transportasi yang mempermudah dan mempercepat laju perdagangan internasional, bahkan telah menempatkan dunia sebagai pasar tunggal bersama. Kedua, meningkatnya kemajuan industri yang diikuti dengan adanya integrasi industri dan perdagangan secara menyeluruh. Ketiga, adanya usaha dari Pemerintah untuk meningkatkan ekspor non-migas. Keempat, adanya usaha dari Pemerintah untuk memajukan industri dalam negeri, baik industri kecil maupun industri menengah yang lebih menyerap tenaga kerja. Kelima, adanya globalisasi perlindungan di bidang HKI sebagai dampak dari ditandatanganinya Persetujuan Putaran Uruguay yang mencakup perjanjian di bidang TRIPs. ${ }^{2}$

'Istilah Hak Kekayaan Intelektual (HKI) mengikuti rumusan resmi yang dipergunakan dalam UU No $\uparrow 4$ Tahun 2001 tentang Paten.

"Emawati Junus." Perubahan atas Undang-undang Paten Tahun 1989." Jurnai Hukum Bisnis. Volume $2 /$ 1997, HIm. 43. 
Sejak tahun 2000, masalah HKI memasuki satu fase baru yang penting dilihat dari perjalanan waktu. Semua negara, kecuali negara terbelakang (least-developed countries) memikul kewajiban sehubungan dengan keterikatan mereka pada kesempatan-kesempatan internasional yang sudah disepakati abad ke$19{ }^{3}$

Dalam bidang paten, Indonesia telah meratifikasi beberapa konvensi Internasional, yaitu Konvensi Paris, Paten Cooperation Trea$t y$, dan Persetujuan TRIPs. Indonesia berkewajiban untuk mengimplementasikan konvensi-konvensi tersebut dalam hukum nasionalnya. Dalam konteks perundangundangan, komitmen Indonesia tidak perlu diragukan. Sampai saat ini, setidaknya terdapat 21 (dua puluh satu) peraturan, baik dalam bentuk Undang-undang, Keputusan Presiden, Peraturan Pemerintah, Keputusan Menteri maupun Surat Edaran Menteri. ${ }^{4}$ Dengan seperangkat hukum tersebut, semestinya Indonesia siap untuk membangun sistem paten yang modern. Tetapi sayang, perangkat dan pemberlakuan hukum yang ada tidak diringi dengan law enforcement yang baik.

Keadaan ini tidak hanya terjadi dalam bidang paten saja, tetapi juga HKI lainnya, sehingga tidak mengherankan bila dalam sebuah seminar di Jakarta, Henessy pakar hukum TRIPs dari Franklin Pierce Law Centre dan Scott M. Martin Wakil Presiden Paramount Pictures sempat berkomentar negatif. Mereka mengatakan bahwa UU HKI Indonesia sudah baik, tetapi dilihat dari fakta dan praktik pembajakan yang terjadi, peraturan yang ada sungguh tidak berjalan efektif. ${ }^{5}$

Untuk mengatasi masalah tersebut, diperlukan kajian mendalam dalam upaya untuk membangun sistem paten pada khususnya dan HKI pada umumnya. Berikut ini akan dibahas beberapa permasalahan penerapan sistem paten di Indonesia disertai upaya untuk membangun sistém paten yang efektif, wajar, dan realistis.

${ }^{3}$ A. Zein Umar Purba. "Peta Mutakhir HaKl." Makalah dalam Kuliah Umum Fakultas Hukum Universitas Islam Indonesia. Yogyakarta. 31 Maret 2000. HIm. 2.

4Peraturan terșebut diantaranya: UU No. 14 Tahun 2001 tentang Paten, UU No. 7 Tahun 1994, tentang Pengesahan Pembentukan WTO, Kepres: No. 15 Tahun 1997 tentang Pengesahan Konvensi Paris, Kepres No. 16 Tahun 1997 tentang Pengesahan PCT dan Regulation Under PCT, Peraturan Pemerintah No. 32 Tahun 1991 tentang Impor Bahan Baku atau Produk Tertentu yang di Lindungi Paten Bagi Produksi Obat dalam Negeri, Peraturan Pemerintah No. 33 Tahun 1991 Tentang Pendaftaran Khusus Konsultan Paten, Peraturan Pemerintah No. 34 Tahun 1991 Tentang Tata Cata Permintaan Paten, Peraturan Pemerintah No. 11 Tahun 1991 Tentang bentuk dan Isi Surat Paten, Peraturan Pemerintah No. 31. Tahun 1995 Tentang Komisi Banding Paten, dan lain: lain. Lebih lanjut bisa dilihat dalam Ansori Sinungan. "Penegakan Hukum dan Litigasi." Makalah disampaikan dalam Training of The Träiner (TOT) Pengelola Gugus HKI Perguruan Tinggi Surabaya dan Semarang. Juli 2000. HIm. 5-6.

5Yoyok Widoyoko. "Pemberlakuan TRIPs, HaKI dan Kesiapan Kita."Harian Republika. 14 Januari 2000. 


\section{Permasailahan yang Dihadapi Indonesia dalam Pelaksanaan Sistem Pāten-}

\section{Minimnya Permohonan. Paten Domestik Indonesia}

Berdasarkan data dari Kantor Paten, sampai akhir Mei $2000^{\circ}$ total permintaan paten di Kantor Paten Indonesia sejumlah 27.957 buaah. Dari jumlah tersebut, permintaan paten dari dalam negeri berjumlah 1.338 buah. ${ }^{6}$ Hal ini berarti permintaan paten domestik hanya. mencapai $4,8 \%$ dari total permintaan. Menurut ketentuan TRIPs, mulai 1 Januari 2000 , negara-negara yang meratifikasi TRIPs dihimbau untuk meningkatkan paten domestik menjadi minimum $10 \%$ dari keseluruhan paten yang didaftarkan. Negara yang gagal akan dimasukkan ke dalam watch list yang berarti bahwa produk ekspornya akan diteliti kandüngan teknologinya dan dipertanyakan asal-usul patennya. ${ }^{7}$ Akibat terburuknya adalah penolakan masuknya barang-barang produk Indonesia ke suatu negara tertentu di Eropa atau Amerika. Belum lagi ada kemungkinan Indonesia dipaksa untuk membayar royalti_kepada sủatu negara yang telah mengklaim patennya atas jenis produk tertentu yang masuk ke Indonesia.

Menurut Insan Budi Maulana, alasan minimnya permintaan paten domestik yang diajukan ke Kantor Paten (Sèkarang Direktörat Jendral HKI) adalah:8

Pertama: sosialisasi paten yang belum. efektif; -tingkạt pemahaman, dan tingkat kesadaran akan arti paten dan sistem hukum paten belum dianggap memadai bagi kalangan peneliti, baik dari lembaga penelitian Pemerintah atau șwasta, termasuk perguruan. tinggi. Sehingga hasil-hasil penelitian yang dilakukan oleh para penelitit, tidak diajukan permintaan patennya.

Kedua: karena faktor ekonomis, yaitu kemampuan para peneliti untuk menyiapkan dana untuk mengajukan permintaan paten yang terbatašs, selain karena situasi.krisis ekonomi, dan belum dipahaminya bahwa paten justru mempunyai manfaat ekonomi apabila penemuan itu berhak atas paten dan digunakan untuk kepentingan umum.

Ketiga: Permintaan paten dianggap sangat birokratis dan memakan waktu lama. Hal ini timbul karena ketidakpahaman para peneliti bahwa prosedur dan proses permintaan paten tidaklah sesederhana sebagaimana yang diduga, selain harus mëmiliki pengetahuan hukum paten dan kemampuan menyusun deskripsi permintaan paten, juga perlu disadari bahwa proses permintaan paten harus mengikuti prosedur yang telah ditentukan, dan hal itu terjadi di manapun.

'Direktorat Paten. "Direktorat Jenderal HaKJ Departemen Huküm dan Perundang-undangan Republik Indonesia." Data Permintaan Paten Pada Kañtor Paten. Jüni 2000.

'Tantono Subagyo. "Perlindungan HaKI di Indonesia." Makalah acuan untuk Sosialisasi HaKI; Tanpa Tahun, HIm. 2. Periksa pula Medi P. Sargo. "Paten Indonesia; Sebuah Impian."Harian Republika:26 Agustus 1999.

'Yayasan Klin̄ik HaKI. Kompilasi Undang-undang Hak Cipta, Paten Merek dan Terjëmahan Konvensi-konvensi di Bidang Hak atas Kekayaan Intelektual (HaK). Seri A. Citra Aditya Bakti. Bandung. 1999. HIm. X. 


\section{Krisis Moneter yang Berkepanjangan}

Krisis moneter yang menghimpit Indonesia telah mendorong meningkatnya pelanggaran HKI, termasuk Paten. Kondisi perekonomian yang semakin terpuruk akibat krisis ekonomi, telah menurunkan purchasing power (daya beli) masyarakat. Dalam situasi seperti ini, dihadapkan pada kenyataan bahwa harga produk yang orisinil atau dilindungi paten sangat mahal, telah mendorong masyarakat untuk "menyuburkan" praktik pembajakan serta pelanggaran terhadap paten. Pelanggaran ini tampak dari hasil survey yang dilakukan oleh Business Software Alliance yang dilansir pada tahun 1997 menunjukkan data bahwa $93 \%$ software komputer yang beredar di Indonesia pada tahun tersebut adalah bajakan. ${ }^{9}$ Akibat pelanggaran tersebut, khusus yang dimilikì orang atau badan hukum dan terdaftar di Amerika Serikat, selama tahun 1997 telah menimbulkan kerugian sebesar US $\$ 226,8$ juta..$^{10}$ Pada tahun 1998 sampai awal tahun 1999, Bea Cukai II Bandara Soekarno Hatta telah menggagalkan masuknya Compact Disk (CD) bajakan sebayak 67.527 unit dengan total kerugian negara sebesar Rp 799 Milyar."

Dalam bidang paten, akibat krisis moneter, pelanggaran paten akan banyak terjadi dalam bidang industri otomotif, farmasi, peralatan rumah tangga, dan lain-lain. ${ }^{12}$ Keadaan ini akan mengakibatkan terjadinya konflik antara negara-negara industri maju dan Indonesia. Bila ini terjadi, Indonesia akan berada pada posisi yang tidak menguntungkan, karena dihadapkan pada Organisasi Perdagangan Dunia (WTO).

Berbeda dengan Thailand dan Philipina, kedua negara ini melalui perundinganperundingan yang keras, berupaya untuk meminta penangguhan pelaksanaan TRIPs kepada WTO sampai tahun 2003-2005 dengan alasan keadaan ekonomi yang memburuk akibat krisis. Hasilnya mereka mendapatkan keringanan penangguhan, tidak hanya dalam bidang obat (farmasi), tetapi juga untuk bidang-bidang lainnya. Indonesia sebenarnya dapat juga mengajukan penangguhan yang sama, hanya saja pada saat sidang WTO di Seattle Amerika Serikat, delegasi Indonesia menyatakan siap menerapkan TRIPs dan bahkan mengaku telah lengkap regulasinya. ${ }^{13}$

\section{Pandangan Masyarakat bahwa Paten adalah Konsep Barat}

Paten merupakan hak eksklusif, di mana bila dilihat dari akar budaya bangsa Indonesia, dapat dikatakan tidak mempunyai akar sejarah

${ }^{9}$ Harian Republika. 9 Januari 1999.

${ }^{10}$ Bambang Kesowo. "Perlindungan Hak Cipta atas Komputer Program." Sambutan Arahan di Seminar Hak Cipta dalam Industri Musik dan Perangkat Lunak Komputer serta Penggunaannya di Indonesia. Diselenggarakan oleh Fakultas Hukum Atma Jaya, bekerjasama dengan P.T. Microsoft Indonesia dan Masyarakat HaKI Indoneisa. Yogyakarta. 28 April 1999. HIm. 2.

"Harian Media Indonesia. 16 Februari 1999.

${ }^{12}$ Insan Budi Maulana. "Penerapan Paten Sejak UU No. 6 Tahun 1989 hingga UU Paten No. 13 Tahun 1997: Pengalaman Indonesia selama ini." Jurnal Hukum. No. 12 Vol. 6. 1999. FH Uil Yogyakarta. HIm. 2.

${ }^{13}$ Harian Kompas. 22 Nopember 2000. 
dan juga tidak terdapat dalam hukum adat. Nilai-nilai falsafah yang mendasari pemilikan individu terhadap karya inovasi dan invensi adalah nilai budaya barat yang menjelma dalam sistem hukumnya. Hal ini jelas berbeda dengan budaya Indonesia yang mengedepankan sikap gotong royong, kebersamaan dan kekeluargaan, sebagaimana dimanifestasikan dalam nilai-nilai Pancasila.

Menurut Salman Luthan, ${ }^{14}$ subtansi nilai yang dikandung dalam TRIPs, sangat menjunjung tinggi kepemilikan individu, termasuk pemilikan hasil karya intelektualitas manusia. TRIPs juga menjunjung tinggi kebebasan individu untuk berekspresi dan mengaktualisasikan diri secara maksimal dalam masyarakat. Di samping itu, TRIPs merupakan bagian dari sistem perdagangan bebas (free trade) yang sangat menghargai prinsip persaingan bebas dan terbuka. Ditinjau dari segi nilai, TRIPs jelas merupakan manifestasi nilai kapitalisme.

Dikarenakan paten dan HKI lainnya tersebut bukan berasal dari nilai-nilai budaya bangsa Indonesia, tetapi nilai-nilai barat yang menjelma - dalam sistem hukum keperdataannya, kadangkala pemberlakuan hak tersebut dalam kehidupan masyarakat menimbulkan pertentangan dengan nilai-nilai budaya tradisional yang telah melembaga dalam kehidupan masyarakat. Artinya dimungkinkan ada perbuatan yáng mënurut Undang-undang.. Paten dikualifikasikan sebagai pelanggaran, akan tetapi:dalam nilainilai budaya masyarakat tersebut tidak dianggap sebagai suatu pelanggaran. Akibatnya masyarakat cenderungan banyak yang mengabaikan atau tidak mematuhi peraturan tersebut.

Faktor-faktor yang mempengaruhi masyarakat untuk tidak mematuhi hukum di bidang HKI antara lain: ${ }^{15}$

a. Pelanggaran HKI pada, ûmumumya dilakukan untuk mengambil jalan. pintäs guna mendapatkan keuntungan yang sebesar-besarnya dari pelaniggaran tersebut.

b. Masyarakat pelanggar mengànggap hukum yang dijatuhkan oleh pengadilan selama ini terlalu ringan 'bähkan tidak pernah ada tindakan-tindakan : preventif maupun represif yang dilakukan 1

c. Ada sebagian masyarakat yang masih merasa bangga apabila hasil karyanya ditiru orang lain.

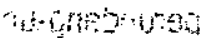

d. Dengan melakukan pelanggàran, pajak atau produk hasil pelanggaranitersebut tidak perlu di bayar kepada"pemerintah:

e. Masyarakat tidak memperhatikan apakah barang tersebut asli atau palsui yang penting bagi mereka adaläh harganya murah dan dapat terjangkau? mi

an $17 \%$

- 药

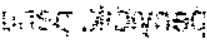

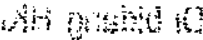

${ }^{14}$ Salman Luthan. "Instrumen Penegakan Hukum Desain Industri, Desain Tata Letak Sirkuit Terpadu, Rahasia Dagang dan Kendalanya." Makalah dalam Seminar Nasional Implementasi Undang-undang Desain Industri, Rahasia Dagang dan Desain Tata Letak Sirkuit Terpadu. Diselenggarakan oleh FH UII bekerja sama dengan Klinik HaKI Jakarta. Yogyakarta. 4 Oktober 2000. HIm. 1.

${ }^{15}$ Ansori Sinunang. Op. Cit. HIm. 2-3. 


\section{Lemahnya Penegakan Hukum}

Suatu peraturan yang baik, tanpa diikuti dengan penegakan hukum yang baik pula, akan sia-sia. Thomas Jefferson menegaskan: "Ignorance of the law is no excuse in any country. If it where, the laws would lose their effect, because it can always be pretended." "16 Tanpa penegakan hukum yang efektif, sistem HKI akan berantakan. Pendaftaran permintaan paten yang dilakukan oleh administrator Direktorat Jendral Hak Kekayaan Intelektual yang atas nama negara memberikan hak kepada pemohon paten akan pupus begitu saja. Karenanya hukum harus ditegakkan. Lemahnya law enforcement ini sebenarnya tidak hanya di bidang HaKl saja, tetapi pada umumnya law enforcement di Indonesia memang lemah. Jadi kalau penegakan HaKI lemah, itu merupakan bagian atau cermin dari lemahnya penegakan hukum secara keseluruhan..$^{17}$

Penegakan hukum ini dipengaruhi oleh beberapa faktor, yaitu: pertama, Peraturan perundang-undangan; kedua, aparat penegak hukum; dan ketiga, kesadaran hukum masyarakat. Secara konseptual, peraturan perundang-undangan di bidang paten, sudah memenuhi standar internasional, baik aturan materiilnya maupun formilnya. Dari ketiga faktor tersebut, yang menjadi kendala bagi penegakan HKl adalah faktor aparat penegak hukum dan kesadaran hukum masyarakat.

Aparat penegak hukum di sini meliputi penyidik, penuntut umum, hakim dan advokat. Di bidang HKI, penyidik dilakukan oleh polisi dibantu oleh Penyidik Pegawai Negeri Sipil (PPNS) Ditjen HKI. PPNS ini dimaksudkan untuk membantu tugas polisi dalam melakukan penyidikan, mengingat pelanggaran $\mathrm{HKI}$ memiliki spesifikasi tersendiri dan membutuhkan keahlian tertentu dalam proses pembuktiannya. Kendala dari aparat penegak hukum di sini tidak hanya terkait dengan jumlah aparat yang terbatas, tetapi juga kualitas aparat penegak hukum. Sebagai contoh, perbandingan jumlah polisi dengan jumlah penduduk di Indonesia adalah 1:1200, padahal menurut PBB, perbandingan yang ideal adalah 1: 400 .

Kualitas aparat penegak hukum, di sini terkait dengan-profesionalitas dan mentalitas pribadi masing-masing. Sampai saat ini wajah peradilan Indonesia masih diliputi awan kelam. Kolusi, korupsi dan nepotisme (KKN) yang seharusnya diberantas, malah bersarang di sana. Praktik mafia peradilan pun sudah menjadi rahasia umum. Akibatnya masyarakat kehilangan kepercayaan pada lembaga peradilan sebagai tempat untuk memperjuangkan keadilan.

Selain itu, kesadaran hukum masyarakat juga menjadi kendala tersendiri dalam penegakan hukum di Indonesia. Budaya kurang menghargai terhadap hasil karya intelektual, bangga bila hasil karya intelektualnya ditin orang lain, serta didukung dengan budaya mengambil jalan pintas untuk meraih keuntungan sebesar-besarnya, mendorong masyarakat untuk melakukan penjiplakan atau peniruan terhadap hasil karya intelektual,

${ }^{16}$ Thomas Jefferson. dalam "Letter to Andre Limozin." 22 Dec 1787, sebagaimana dikutip oleh A. Zen Umar Purba. "Penegakan Hukum di Bidang HaKl." Harian Kompas. 22 Mei 2000.

${ }^{17} /$ bid. 
dengan perasaan tanpa salah dan tiada pertanggungjawaban. Hal ini dapat dilihat dari maraknya penjualan produk-produk hasil pelanggaran $\mathrm{HKI}$ yang bisa dijumpai di manamana. Masyarakat memandang seolah-olah kegiatan tersebut adalah legal, sedangkan aparat penegak hukum (polisi) sendiri tidak dapat bertindak banyak menghadapi masalah tersebut. ${ }^{18}$

Akibat lemahnya penegakan HKI ini, pada tahun 1999 oleh USTR Indonesia dimasukkan dalam kategori priority watch list, yaitu negara yang dalam pengawasan khusus. Dengan status ini, produsen Indonesia dalam memasarkan produk di Amerika akan mendapatkan perlakuan atau hambatan yang pada akhimya dapat melemahkan daya saing dan penetrasi pasar Indonesia di Amerika, misalnya dengan pemeriksaan yang detail dan bertele-tele mengenai kandungan teknologi dan rincian asal-usul paten hingga diyakini tidak sampai merugikan atau melanggar HKI warga Amerika. Berkat kemajuan penegakan HKI, sejak 1 Mei 2000, posisi Indonesia membaik, yaitu menempati posisi watch list.

Untuk meningkatkan pelaksanaan penegakan $\mathrm{HKI}$ di Indonesia, Ditjen HKI sebagai pihak yang paling berkompeten telah mencanangkan empat langkah strategis, yaitu: (1) merevisi atau mengubah peraturan perundang-undangan yang telah ada di bidang HKI untuk disempurnakan lagi; juga mempersiapkan penyertaan indonesia dalam konvensi-konvensi internasional; (2) menyempurnakan administrasi pengelolaan sistem HKI dan meningkatkan pelayanan kepada masyarakat; (3) memasyarakatkan atau sosialisasi HKl; dan (4) membantu penegakan hukum di bidang HKI. ${ }^{19}$ Keempat langkah strategis di atas, diharapkan mampu mengatasi permasalahan yang menghambat pelaksanaan ketentuan internasional tentang paten.

\section{Membangun Sistem Paten Indonesia yang Efektif, Wajar dan Realistis}

Berbicara tentang sistem paten, tentunya mencakup banyak komponen yang terkait dengan paten. Sistem ini meliputi sub-sub sistem yang masing-masing saling terkait dan saling berinteraksi, sehingga membentuk sistem paten. Untuk membangun sistem paten yang efektif, wajar dan realistis, setidaknya harus dibicarakan tentang bidang-bidang strategis yang mendukung pelaksanaan sistem paten, seperti peraturan perundangundangan (hukum paten), sistem pendidikan nasional, pola pembangunan dan pengembangan teknologi nasionàl, peran serta organisasi penelitian "dan pengembangan (Litbang), dan kebijakan strategis Ditjen HKI. Berikut akan dibicarakan masing-masing komponen tersebut:

${ }^{18} \mathrm{Pelanggaran} \mathrm{HK}$ yang ditindak polisi, biasanya yang bersekala besar, seperti terlihat pada penggrebekan terhadap perusahaan penggandaan piringan cakramVCD ilegal di Tangerang Harian Kompas, 9 Agustus 1999, di Batam Harian Suara Pembaharuan. 21 Januari 2000 dan razia VCD bajakan di Glodok Majalah Forum Keadilan, No. 8, 28 Mei 2000.

${ }^{19}$ A. Zen Umar Purba. Op. Cit. HIm. 2. 
1. Penyempurnaan

Peraturan

Perundang-Undangan di Bidang Paten

Pada tanggal 1 Agustus 2001, pemerintah telah mengesahkan UU Nomor 14 Tahun 2001 tentang Paten sebagai pengganti UU Paten sebelumnya. UU tersebut melengkapi dan menyempurnakan hukum paten terdahulu. Beberapa perubahan penting dalam Undangundang tersebut adalah:

a. Pengaturan penetapan sementara oleh Pengadilan (injunction) ${ }^{20}$.

Injunction diatur dalam Ketentuan TRIPs Pasal 44, di mana negara anggota diharuskan untuk memberikan kewenangan kepada otoritas yudisial untuk memerintahkan suatu pihak mencegah berlanjutnya pelanggaran $\mathrm{HKl}$, -termasuk paten dan hak yang berkaitan dengannya. P.engaturan ini efektif untuk mencegah masuknya barang yang diduga melanggar paten dan hak yang berkaitan dengan paten ke dalam jalur perdagangan termasuk tindakan importasi dan atau menghentikan sementara peredaran produk yang diduga melanggar paten. Hal ini dapat mengantisipasi kerugian lebih besar yang diderita oleh pemilik paten atau pemegang lisensi akibat perbuatan pelanggaran paten.

b. Perubahan istilah penemuan menjadi invensi dan penemu menjadi inventor

c. Invenși yang tidak dapat dipatenkan, termasuk didalamnya adalah invensi tentang makhluk hidup (mencakup manusia, hewan dan tanaman). ${ }^{21}$ Alasan tidak dapat dipatenkannya invensi tentang manusia karena hal itu bertentangan dengan moralitas agama, etika, dan kesusilaan.

d. Penyelesaian sengketa melalui Pengadilan Niaga. ${ }^{22}$ Berdasarkan UU Nomor 4 Tahun 1998, di lingkungan Peradilan Umum dibentuk Pengadilan Niaga yang berwenang untuk memeriksa dan memutus perkara di bidang perniagaan yang penetapannya dilakukan dengan Paraturan Pemerintah. Mengingat paten ini termasuk bidang perniagaan, di mana dalam pemeriksaannya membutuhkan keahlian khusus, maka untuk prosedur perdata sebaiknya memang menjadi kewenangan Pengadilan Niaga untuk memeriksa dan memutusnya. Dengan demikian diharapkan sengketa paten dapat ditangani oleh orang-orang yang berkompeten dan dapat diselesaikan secara profesional.

e. Penyempurnaan peraturan yang terkait dengan paten sederhana, di antaranya:

(1) Kebaharuan Universal ${ }^{23}$

Persyaratan kebaharuan universal ini penting, terutama bila dikaitkan dalam pelaksanaan penelusuran referensi (dokumen pembanding) yang dapat digunakan, sebagai contoh CD-ROM yang berisikan publikasi permohonan paten dari Kantor Paten Eropa, Publikasi Paten di Amerika Serikat, dan Jepang. Apabila diingat bahwa saat ini akses untuk melakukan penelusuran atau mengetahui informasi dapat dilakukan melalui

${ }^{20}$ Pasal 125 UU Nomor 14 Tahun 2001

2'Pasal 7 UU huruf $d$ Nomor 14 Tahun 2001. Lihat juga penjelasan Umum UU Nomor 14 Tahun 2001 angka. 2 huruf $d$.

${ }^{22}$ Pasal 117 ayat (1) UU Nomor 14 Tahun 2001

${ }^{23}$ Pasal 105 ayat (5) UU Nomor 14 Tahun 2001 
internet, maka perbedaan pelaksanaan penelusuran untuk sistem kebaruan lokal atau universal menjadi rancu. Dengan dipersyaratkannya kebaruan universal, maka kendala yang dihadapi akan dapat diatasi dan penelusuran yang dilakukan melalui akses ke internet tidak menjadi masalah.

(2) Sistem Terbuka ${ }^{24}$

Dengan sistem terbuka ini, permohonan paten sederhana akan diumumkan, sehingga masyarakat/pihak ketiga dapat mengajukan keberatan yang dapat merupakan masukan yang berguna bagi Direktorat Jendral, terutama dalam pemeriksaan subtantif untuk mempertimbangkan sebelum memberikan keputusan.

(3) Paten sederhana diberikan untuk satu invensi $^{25}$

Sebelumnya, penemuan dibatasi pada satu klaim, sehingga sulit bagi pemohon untuk mendapatkan perlindungan yang memuaskan sesuai keinginannya. Karena dengan klaim yang berjumlah 1 (satu) jika ciri teknis (feature) penemuan terlalu banyak dalam satu klaim, maka lingkup perlindungannya akan sempit. Sebaliknya, apabila ciri-ciri teknis tersebut dikurangi, maka pelindungan akan menjadi terlalu luas, akan tetapi rentan terhadap kemungkinan diantisipasi oleh referensi yang ada (prior art).

Dengan tidak dibatasi jumlah klaimnya, akan tetapi dibatasi untuk 1 (satu) penemuan, diharapkan pemohon dapat membuat klaim secara leluasa, walaupun hanya untuk satu penemuan saja dalam setiap permohonannya.

f. Pengajuan melalui permintaan internasional (Traktat Kerja Sama Paten/ PCT.) ${ }^{26}$

Pengaturan ini sebagai konsekuensi keikutsertaan indonesia dalam meratifikasi Traktat Kerja Sama Paten berdasarkan Keputusan Presiden Nomor 16 tahun 1997.

Di samping, mesti menyesuaikan UU Paten dengan ketentuan internasional yang telah diratifikasi, harus pula mempertimbangkan kepentingan bangsa dan negara, mengingat pembentukan UU Paten selain karena konsekuensi keikutsertaan Indonesia pada konvensi internasional, tentunya dimaksudkan juga untuk meningkatkan kemampuan teknologi bangsa serta menggairahkan kegiatan penelitian di dalam negeri. Oleh karena itu, tanpa mengesampingkan, "aturan permainan internasional", Indonesia dituntut untuk membangun hukum paten yang efektif, wajar, dan realistis, sehingga permintaan paten . domestik bisa meningkat dan mengimbangi. permintaan paten asing. Berikut beberapa hal yang dapat dipertimbangkan untuk mewujudkan hukum paten yang dimaksud, yaitu:

a. Penerapan lisensi wajib /compulsory lecense) secara ketat ${ }^{27}$ dan pengecualian penemuan yang dapat dipatenkan secara luas. ${ }^{28}$

\footnotetext{
${ }^{24}$ Pasal 105 ayat (4) UU Nomor 14 Tahun 2001.

${ }^{25}$ Pasal 105 ayat (1) UU Nomor 14 Tahun 2001.

${ }^{26}$ Pasal 109 UU Nomor 14 Tahun 2001.

${ }^{27}$ Ketentuan lisensi wajib diatur dalam Pasal 74-87 UU Nomor 14 Tahun 2001.

${ }^{28}$ Ketentuan ini diatur Pasal 7 UU Nomor 14 Tahun 2001.
} 
Lisensi wajib dan pengaturan pengecualian penemuan yang dapat dipatenkan secara luas merupakan dua ciri hukum paten yang banyak dianut oleh kebanyakan negara-negara berkembang. Lisensi wajib diatur dalam Konvensi Paris Pasal 5 A (2) dan (5). Pemberlakuan lisensi ini diharapkan mampu meningkatkan kemampuan teknologi bangsa. Dengan pemberlakuan lisensi wajib, pemilik paten "dipaksa" melaksanakan patennya di indonesia, karena apabila dalam jangka waktu 36 (tiga puluh enam) bulan paten itu tidak dilaksanakan, padahal kesempatan untuk melaksanakannya secara komersil sepatutnya ditempuh, maka berdasarkan putusan Direktorat Jenderal, lisensi wajib dapat ditetapkan. Hal yang dimaksud penerapan secara ketat di sini adalah pemerintah bertindak tegas terhadap semua pemilik paten yang didaftarkan di Indonesia, sehingga pilihan pemegang paten hanya dua, yaitu melaksanakan penemuannya di Indonesia dan/ melisensikannya atau ditetapkannya lisensi wajib. Dengan demikian diharapkan sistem paten dapat mendukung proses alih teknologi.

Pengaturan pengecualian penemuan yang dapat dipatenkan, ${ }^{29}$ didasarkan pada kenyataan bahwa sampai saat ini permintaan paten pada Direktorat Jenderal HKI masih didominasi pihak asing. Untuk itu dengan adanya pengecualian yang luas, banyak bidang-bidang tertentu yang tidak bisa diberlakukan sistem paten, karena bidang- bidang tersebut merupakan bidang yang sangat penting yang menguasai hajat hidup orang banyak, sehingga tidak etis bila penemuan itu dilindungi hak eksklusif, yang mengakibatkan kepentingan masyarakat terbaikan

\section{b. Masa berlakunya perjanjian lisensi}

Menurut Pasal 69 ayat (2) masa berlakunya perjanjian lisensi adalah sesuai dengan jangka waktu lisensi diberikan. Berdasarkan asas kebebasan berkontrak, tiap-tiap pihak memang berhak untuk mengadakan perjanjian sesuai dengan kehendaknya masing-masing. Namun bila ini dikaitkan dengan masa berlakunya hak eksklusif yang diberikan paten (yaitu 20 tahun), maka bisa jadi paten yang sudah kadaluwarsa perjanjian lisensinya masih tetap berlaku. Konsekuensinya, teknologi yang semestinya sudah menjadi domain publik, dan semua orang bebas untuk menggunakannya, namun karena lisensi masih berlaku, licencee tetap terikat dengan perjanjian lisensi. Pengaturan semacam ini jelas merugikan kepentingan licencee. Mengingat dalam kenyataan bahwa banyak warga kita yang menempati posisi sebagai licencee, maka perlu dipertimbangkan untuk mengubah berakhirnya masa berlakunya lisensi yaitu dibatasi dengan berakhimya masa perlindungan paten dan/atau berakhirnya masa waktu yang diperjanjikan.

c. Pengaturan prosedur pidana ${ }^{30}$

${ }^{29}$ Ketentuan ini datur dalam Pasal 27 ayat 3 Persetujuan TRIPs.

${ }^{30}$ TRIPs tidak mewajibkan negara anggota untuk menyediakan mekanisme pidana dalam bidang paten. Pasal 6I TRIPs hanya mewajibkan menyediakan aturan pidana untuk tindak pidana pembajakan hak cipta dan pemalsuan merek dagang. Oleh karena itu pula, dalam Hukum Paten Amerika Serikat, tidak dijumpai adanya prosedur kriminal. 
Ketentuan pidana diatur dạlam Pasal 130, 131, dan 132 UU Paten, yaitu berupa sanksi pidana penjara dan/atau denda. Perubahan UU paten telah mengganti pelanggaran paten dari delik biasa menjadi delik aduan. Namun demikian, di masa mendatang perlu dipertimbangkan agar prosedur pidana tidak diatur lagi. Jadi cukup dengan prosedur gugatan secara perdata.

\section{Membenahi Sistem Pendidikan}

Sebaik apapun UU paten yang dimiliki, tanpa didukung oleh sumber daya manusia yang siap berkompetisi untuk menghasilkan penemuan yang berkualitas paten, maka UU itu tidak akan mencapai tujuannya untuk meningkatkan kemampuan teknologi bangsa. Bahkan bisa jadi UU itu hanya memfasilitasi pihak asing untuk mendapatkan perlindungan paten di İndonesia: Oleh karena itu, hukum paten akan efektif bila ditunjang kemampuan SDM yang handal pula. Berbicara tentang kualitas SDM, maka tidak bisa dilepaskan' diri dari pembahasan tentang sistem pendidikan nasional.

- Sebagaimana Jepang, Amerika Serikat, dan negàra-negara industri maju lainnya, keberhasilan mereka dalam meningkatkan kemampuan teknologinya dimulai dari peletakan dasar-dasar péndidikan yang sistematis. Jepang misalnya, dalam pembangunan sistem patennya yang dimulai pada masa Pemerintahan Meiji, dibangun bersamaan dengan pembangunan sistem pendidikan: Yukichi Fukuzawa sebagai peletak dasar hukum paten di Jepang, ia juga dikenal sebagai peletak sistem pendidikan di sana, yang bertujuan untuk membangun SDM dalam menghadapi modernisasi di negaranya. Pembangunan sistem paten Jepang yang dimulai tahun 1885 , di mana pada saat itu hampir semua pemohon paten berasal dari asing, namun berbekal dengan modernisasi dan pembangunan yang dihasilkan dari sistem pendidikan Jepang, sekarang ini mayoritas paten di Jepang dimiliki oleh orang Jepang sendiri. ${ }^{31}$ Sehingga sangat tepat, bila Yoshiro Sumida mengatakan bahwa pendidikan adalah kunci untuk meraih keuntungan dari sistem paten. ${ }^{32} \mathrm{Hal}$ yang sama juga terjadi di Amerika dan Eropa Barat, kesadaran akan pentingnya pendidikan inilah yang melahirkan renaissance, sehingga mereka dapat menjadi negara industri maju dengan kemampuan inovasi teknologi yang tinggi (technological innovators).

Dalam Pandangan Jeffrey Sachs yang membagi dunia dari sudut teknologi menjadi tiga kelompok, yaitu technological innovators, technological adopters, dan technologically excluded, Indonesia bisa dikategorikan dalam kelompok technological adopters, yaitu negara yang mampu menguasai teknologi-teknologi baru hasil inovasi, terutama teknologi produksi

${ }^{31}$ Menurut catatan WIPO, pada tahun 1997, permohonan paten domestik Jepang mencapai 13\% (430.022 buah) dari total permintaan paten pada JPO yang mencapai 3.333 .753 buah, kemudian pada urutan berikutnya Amerika Serikat dengan jumlah $236.692(7 \%)$ dan Korea dengan jumlah $(5,2 \%)$.

${ }^{32}$ Yoshiro Sumida. "The Role and Implementation of Patent Law in 21 st Century, The Possible Conflict Between Developed and Developing Countries." Makalah di sampaikan dalam Seminar Nasional Peranan Hak Cipta, Paten dan Merek dalam Pembangunan Perdagangan dan Industri. Kerja sama FH UII dan Klinik HKI Jakarta. Yogyakarta. 9 Desember 1998. HIm. 2. 
dan konsumsi. Namun menurut Mochtar Buchori, ${ }^{33}$ bila Indonesia tidak berbuat sesuatu untuk meningkatkan kemampuan bangsa dalam teknologi, tidak mustahil status Indonesia sebagai technological adopters kian menurun, dan suatu saat posisi ini akan lepas dari genggaman Indonesia.

Karena itu, upaya untuk meningkatkan kemampuan bangsa dalam hal teknologi pada generasi muda menjadi agenda yang harus diprioritaskan. Dalam hal ini Buchori menawarkan dua langkah dasar untuk mencapai tujuan itu..$^{34}$ Pertama, mendorong kelompok-kelompok tertentu di masyarakat agar berkembang menjadi kantung-kantung inovasi teknologi: Pada dasarnya Indonesia sudah memiliki kantung-kantung ini, hanya jumlahnya terlampau kecil. Kedua, mengusahakan agar wilayah-wilayah yang kini bersifat terkucil secara teknologis, berangsurangsur ditingkatkan menjadi wilayah yang berkemampuan mengadopsi hasil-hasil inovasi. Lebih lanjut, Buchori menjelaskan bahwa kedua hal itu tidak bisa dilakukan begitu saja. Dibutuhkan waktu untuk menumbuhkan generasi berkemampuan mengadopsi inovasi teknologi dan mampu mengadakan inovasi teknologi. Untuk itu jalannya hanya satu, yaitu pembaruan pendidikan Matematika dan limu Pengetahuan Alam (MIPA). ${ }^{35}$

Bila Indonesia ingin betul-betul meningkatkan kemampuan di bidang teknologi di masa depan, maka tidak boleh ada anakanak muda yang buta matematika (matematically illiterate) dan buta IPA (scientifically illiterate). Memang tidak semua siswa berminat menjadi ahli matematika, IPA atau teknologi, tetapi suatu masyarakat akan berhasil mengembangkan kemampuan teknologi yang cukup tinggi bila ada lapisanlapisan penduduk dengan tingkat pemahaman matematika dan ilmu pengetahuan yang bersifat expert, sampai yang bersifat apresiatif.

Menurut Lord Snow, sebagaimana dikutip Buchori, ${ }^{36}$ pada dasarnya tiap masyarakat yang ingin mengalami "revolusi ilmiah" (scientific revolution), yaitu loncatan raksasa dalam penguasaan MIPA harus mampu mengembangkan empat lapisan penduduk dengan penguasaan MIPA yang berbedabeda. Paling atas lapisan alpha plus scien: tist, yaitu ilmuwan-ilmuwan pengetahuan alam dengan kemampuan amat tinggi yang jumlahnya di bangsa manapun tidak pernah besar. Lapisan kedua, kelompok alpha professions, jumlahnya lebih besar dari kelompok pertama, bertugas melakukan supporting research, the high class design and development. Di lapisan ketiga ada ilmuwan-ilmuwan yang melakukan secondary technical job. Lapisan keempat adalah politisi, birokrat, dan masyarakat umum dengan pemahaman MIPA memadai, sehingga mereka mengerti apa yang dibicarakan para ilmuwan (natural scientist).

Untuk dapat mewujudkan empat lapisan ini di Indonesia, tentunya dibutuhkan waktu dan usaha keras, dan yang tidak bisa ditinggalkan adalah bagaimana mereformasi pendidikan

\footnotetext{
${ }^{33}$ Mochtar Buchori. "Meningkatkan Kemampuan Teknologi Bangsa." Harian Kompas. 11-12 September 2000.

${ }^{34} / \mathrm{bid}$.

${ }^{35}$ Ibid.

${ }^{36} /$ bid.
} 
Aatematika dan IPA dari tingkat Pendidikan Jasar (SD dan SLTP), Pendidikan Menengah SMU), termasuk pula pendidikan tinggi pada kkultas-fakultas tertentu, khususnya MIPA dan oknologi, sehingga program Pendidikan MIPA lapat dicerna dengan mudah oleh tiap peserta idik.

\section{;. Budaya Masyarakat}

Di antara permasalahan yang menyebabkan linimnya permintaan paten domestik idonesia dan lemahnya penegakan hukum raten adalah budaya (culture) masyarakat ndonesia yang kurang menghargai hasil arya intelektual serta kecenderungan untuk 1engambil "jalan pintas" dalam rangka meraih euntungan yang sebesar-besarnya. Selain u masih banyak kelompok masyarakat yang venganggap makin banyak karya seseorang ititu oleh pihak lain, akan semakin baik bagi i penemu atau pencipta. Artinya dia makin luas ikenal dan bertambah populer. Rendahnya emohonan paten lokal pada sisi lain erkaitan dengan persepsi. Baik aspek ultur maupun persepsi tidak bisa dilepaskan erigan masalah peningkatan pemahaman lasyarakat akan HKI, termasuk di dalamnya aten. Untuk itu sosialisasi menjadi langkah ang strategis dalam pembangunan budaya lasyarakat menuju masyarakat yang sadar an menghargai $\mathrm{HKI}$.

- Dalam masalah penyebarluasan emahaman ini, Pemerintah memegang eranan yang sangat penting, karena walau agaimanapun, Pemerintahlah yang pada dasarnya paling berkepentingan dan bahkan bertanggung jawab terhadap pelaksanaan segala Undang-undang dan peraturan pelaksananya. Teori "fiksi hukum" tampaknya tidak cukup dijadikan dasar bahwa semua orang sudah memahami dan mengerti suatu peraturan yang ditempatkan dalam Lembaran Negara. Lebih penting dari itu, perlu ada usaha yang sungguh-sungguh untuk menyebartuaskan pemahaman materi UU tersebut kepada masyarakat termasuk aparat Pemerintah, khususnya penegak hukum.

Menurut Bambang Kesowo, sistem hukum memang tidak terwujud dan dapat ditegakkan bilamana kegiatan hanya berhenti pada pembentukan peraturan perundangundangan. ${ }^{37} \mathrm{Hal}$ yang sama berlaku pula pada HKI. Hasil pengamatan selama ini menunjukkan bahwa kurangnya pemahaman terhadap masalah tersebut akan mempengaruhi tingkat kesadaran terhadap hak-hak yang dimiliki, mengenai kapan dan bagaimana harus menegakkan atau mempertahankan hak itu sendiri.

Aparat penegak hukum, baik polisi, jaksa, hakim, maupun pengacara, harus betul-betul memahami ketentuan yang diatur dalam undang-undang, karena mereka inilah yang akan secara langsung bersinggungan dengan upaya penegakan hukum. Seiring dengan langkah sosialisasi di kalangan aparat penegak hukum, pemahaman mengenai hal itu juga perlu diarahkan kepada masyarakat secara umum, agar mereka menyadari ,hak dan kepentingannya. Apresiasi juga harus tetap tumbuh dari,kalangan pelaku HKI sendiri,

${ }^{37}$ Bambang Kesowo. "Perlindungan Hukum serta Langkah-langkah Pembinaan oleh Pemerintah dalam .jdang Hak Milik Intelektual." dalam Paten, Pengaturan dan Pelaksanaan. Pusat Pengkajiana Hukum. akarta. 1993. HIm. 24. 
baik itu pengusaha, peneliti, akademisi dan pihak-pihak lainnya yang secara langsung bersinggungan dengan .HKI: Merekalah yang seyogyanya berkepentingan dalam hal ini, terutama dalam upaya melindungi hak dan kepentingannya.

\section{Pola Pembangunan Teknologi Nasional}

Pembangunan teknologi sebagai bagian dari pembangunan nasional pada umumnya, merupakan sarana untuk mewujudkan manusia Indonesia seutuhnya yang berkeadilan dan berkemakmuran. Kebijakan Pemerintah dạlam bidang teknologi akan banyak berpengaruh terhadap kemampuan manusia Indonesia dalam penguasaan dan pencapaian teknologi, yang pada gilirannya akan berpengaruh pada kesejahteraan dan kemakmuran masyarakat.

Pencapaian teknologi tidak bisa dilepaskan dari kegiatan riset, karena melalui kegiatan inilah dapat dihasilkan berbagai macam teknologi. Lembaga Penelitian non-Departemen (LPND) -seperti LIPI, BBPT, BATAN, LAPAN, BAKOSURTANAL, Lembaga Eijkman, dan PUSPIPTEK, sebagai pelaku utama keǵiatan riset di Indonesia, dalam hal ini diharapkan dapat menjalankan tugasnya dengan baik, karena LPND ini 'merupakan anak kandung dari Kementrian Riset dan Teknologi yang menempatkan kegiatan Ristek sebagai kegiatan utama: Sedangkan Litbang sektoral di departemen teknis termasuk Depdiknas, riset masih belum dianggap penting.

: "Dimulai dari era Sumitro, produk utama kementrian Ristek adalah gagasan tentang pemusatan kemampuan riset dan teknologi
(Ristek) di kawasan Puspiptek Serpong yan baru terwujud pada tahun 1976 pada saat $B$. Habibie menjadi Menteri Negara Ristek Melalui usahia keras Habibie, lahirlah Industt Pesawat Terbang Nasional (IPTN) yane kemudian diekstrapolasikan menjadi jugi industri transportasi, dan selanjutnya industr strategis. ${ }^{38}$ Sisa anggaran ristek bersami dengan bantuan dan pinjaman luar neger dipakai untuk membangun fasilitas baru peralatan banu dan meningkatkan SDM denga: pendidikan S-3 yang kemudian kembali pad awal 1990-an.

Pada tahun 1997 ketika krisis ekonor menerpa Indonesia, bulan madu yan: berlangsung lama itu segera berakhir, bersami dengan berakhimya kepemimpinan Habibiø sebagai Menristek. Pada saat itu, dunia Riste' mengalami kesulitan dalam pendanaan sehingga industri strategis termasuk IPTN yan: belum mampu mendanai sendiri kegiatanny: segera ambruk. Menegristek Pasca Habibie Rahardi Ramelan yang hanya beberapa bular Zuhal yang sekitar setahun maupun AS Hikar. pada pemerintahan Abdurrahman Wahid mengalami permasalahan yang sangat berat Di 'satu sisi sumber dana sangat terbatas, $c$ sisi 'lain pelaku ristek belum siap untuk berkinerja pada skala ekonomi. Walaupur bekerja di bawah 'sikap skeptis masyaraka! AS Hikam mencoba menjawabnya dengas merumuskan beberapa arahan sepert Kebijakan Strategis (Jakstra) dan Priorita: Utama Nasional untuk Riset dan Teknolos (Punas Riștek), sebagai panduan bagi pelak! utama Ristek untuk berkinerja dengan sebaik baiknya. ${ }^{39}$

\footnotetext{
${ }^{38}$ S. Farida Ruskanda. "Iptek Indonesia, Sebuah Refleksi dan Perspektif." Harian Republika. 3Januari200" ${ }^{39}$ Ibid.
} 
Pada tahun 2001 penelitian akan banyak diarahkan dalam bidang kelautan seirama dengan intensifnya bidang ini. Pengembangan teknologi tepat guna juga akan banyak diarahkan untuk mendukung industri kecil dan menengah dalam memulihkan kondisi perekonomian nasional. Dengan terbatasnya anggaran.penelitian, maka akan banyak penelitian dalam bidang elektronika yang bersifat software khususnya dalam tingkat aplikasi. Pemantauan lingkungan serta pengolahan limbah akan terus ditekuni mengingat menggebunya semua pihak pada sektor ini. Secara umum penelitian rekayasa, proses maupun metode untuk industri berbasis sumber daya alam akan sangat menonjol pada tahun 2001 untuk lebih mengoperasionalkan sektor ristek ini pada pemulihan ekonomi: ${ }^{40}$

Di samping itu, sebagai pengemban kemajuan teknologi, Kantor Menteri Negara Riset dan Teknologi juga memiliki tanggung jawab dalam upaya peningkatan kemampuan teknologi bangsa. Sebagai usaha untuk meningkatkan pemakaian teknologi temuan para peneliti Indonesia, Pemerintah melalui Kantor Menteri Negara Riset dan Teknologi mulai tahun anggaran 2000 akan mengeluarkan beberapa program, yaitu:

a. Program insentif asuransi teknologi. Pada program ini industri yang lolos seleksi akan memperoleh premi untuk mengembangkan suatu temuan teknologi yang dilakukannya, dari skala laboratorium hingga skala produksi massal.41

b. Program insentif "olah Paten" yaitu pemberian subsidi kepada para peneliti yang akan mematenkan hasil temuannya, besarnya Rp. $5.000 .000,00$ untuk setiap peneliti. Program ini dilaksanakan selama 5 tahun dan akan dimulai pada tahun anggaran 2000. Jumlah usulan yang akan dibiayai tahun anggaran 2000 ini sebanyak 60 usulan. ${ }^{42}$

c. Pemberian subsidi kepada Sentra HKl yang ada di Perguruan Tinggi atau lembagalembaga penelitian pemerintah maupun swasta, besarnya Rp. $75.000 .000,00$ untuk setiap sentra HKI. Tahun ini yang mendapatkan subsidi sebanyak 11 Sentra HKI, diantaranya: LIPI, Balitbang Departemen Pertanian, IPB, UGM, UI, ITS Surabaya, Universitas Diponegoro, ITN Bandung, Asosiasi Penelitian Perkebunan Indonesia, dan Politeknik Negeri Lhokseumawe. ${ }^{43}$

d. Program STANLAB (Standarisasi Laboratorium) dengan jalan memberikan subsidi biaya pemeliharaan dan peningkatan kualitas laboratorium, besarnya subsidi ini adalah $\mathrm{Rp}$. $50.000 .000,00$ untuk setiap laboratorium. Laboratorium yang mendapatkan insentif ini sebanyak 25 laboratorium.4

Dari uraian di atas, penulis ingin menunjukkan bahwa kebijakan nasional

\section{${ }^{40} /$ bid.}

${ }^{41}$ Harian Kompas. 24 Januari 2001.

${ }^{42}$ Harian Republika. 16 September 2000.

${ }^{43} \mathrm{lbid}$.

${ }^{44}$ /bid. 
dalam menentukan strategi pembangunan teknologi akan sangat berpengaruh terhadap pencapaian dan penguasaan masyarakat terhadap teknologi. Pemberian berbagai insentif diharapkan mampu meningkatkan motivasi para peneliti Indonesia menghasilkan inovasi teknologi. Dalam hal ini dunia Ristek harus bekerja sama dengan dunia pendidikan untuk mewujudkan sinergi, sehingga Lembaga Ristek dapat didukung oleh SDM yang berkualitas yang pada muaranya akan mampu menghasilkan teknologi yang berkualitas tinggi. Dengan adanya gerak denyut nadi dunia Ristek yang dinamis, diharapkan banyak muncul penemuan di bidang teknologi yang siap untuk dipatenkan. Dengan demikian hukum paten yang dipersiapkan untuk meningkatkan kemampuan teknologi bangsa dapat dimanfaatkan oleh anak bangsa sendiri untuk mewujudkan kemakmuran dan kesejahteraan bersama.

\section{Pemberdayaan Lembaga Penelitian dan Pengembangan (Litbang) serta Peningkatan Gairah Peneliti}

Dewasa ini, terjadi kemajuan pesat di bidang penelitian dan pengembangan, khususnya yang menyangkut aspek terapan yang dapat berguna langsung bagi masyarakat. Teknologi yang berguna langsung bagi masyarakat tersebut pada umumnya dapat dikomersilkan. Oleh karena itu, penghasil teknologi berusaha agar teknologi tersebut mendapat perlindungan sehingga nilai komersial teknologi tetap berada di tangan pencipta atau pemegang lisensi. Di negara-negara maju, seperti Amerika Serikat, Jepang dan negara Eropa Barat lainnya, kemajuan teknologi paten banyak bertumpu pada kegiatan Research and Developing (R/D). Karena itu, kegiatan R/D menempati posisi penting dalam setiap kesempatan, dan pembiayaannya pun mendapatkan prioritas.

Di Indonesia sendiri, Lembaga Litbang telah dikenal secara luas. Setiap perusahaan biasanya memiliki devisi Litbang, demikian pula organisasi sosial politik dan kemasyarakatan, lembaga pemerintahan, lembaga swasta, serta lembaga pendidikan tinggi. Organisasi seperti LIPI dan BATAN misalnya, yang sering dikategorikan sebagai Organisasi Penelitian dan Pengembangan (OPP), diharapkan dapat menciptakan. pemahaman ilmiah baru dan inovasi teknologi, yang menjadi sumbangan dari OPP itu bagi pembangunan, yang bermuara ke industri dan dunia ekonomi. Karena kinerja OPP itu penting, tidaklah berlebihan bila Indonesia mengharapkan dari suatu OPP tingkat ke"penemuan"an yang tinggi dan terus meningkat dari waktu ke waktu. 45

Divisi Litbang di sini memiliki peranan yang penting dalam memajukan organisasi serta menumbuhkan kreasi-kreasi baru untuk meningkatkan kinerja dan pencapaian teknologi baru. Bagi perusahaan-perusahaan yang ingin maju, semestinya menginvestasikan dana yang besar untuk kegiatan Litbang, sehingga melalui kegiatan tersebut diharapkan lahir teknologi-teknologi baru yang memiliki arti penting dalam meningkatkan

${ }^{45}$ Amru Hydari Nazif. "Paten dan Pengelolaan Penelitian dan Pengembangan." Makalah dalam Seminar Paten dan Teknologi Nuklir dalam Rangka Meningkatkan Daya Saing Bangsa. Badan Tenaga Nuklir Nasional. Jakarta. 18 Agustus 1999. HIm. 3. 
kinerja dan produksi perusahaan. Demikian juga lembaga pemerintahan dan swasta yang ingin tetap eksis dalam kompetisi global, juga dituntut untuk menggalakkan kegiatan Litbangnya. Hasil dari kegiatan Litbang ini bila kemudian memenuhi kualifikasi syarat-syarat paten, maka bisa menjadi aset yang berharga bagi penelitinya maupun lembaga yang bersangkutan.

Hal yang sama juga berlaku bagi lembaga penelitian yang ada di lingkungan Perguruan tinggi (PT). PT sudah selayaknya mengadakan dan menggiatkan kegiatan-kegiatan di bidang penelitian yang berorientasi pada paten. Hampir semua PT memiliki Lembaga Penelitian, sehingga secara kuantitas jumlah Lembaga Penelitian di PT sudah memadai, namun secara kualitas hasilnya sangat minim. Demikian juga kegiatan penelitian individual dosen maupun mahasiswa, belum menunjukkan hasil yang signifikan dalam mendukung permintaan paten domestik. Sebenarnya para peneliti Indonesia memiliki kemampuan yang cukup memadai, hal itu setidaknya tampak dalam beberapa pameran yang menggelar teknologi dan karya-karya ilmiah. Semua inovasi dan invensi dipamerkan. Tetapi sayang para peneliti Indonesia hanya bangga dengan penghargaan dan prestasi yang diraihnya dan melupakan begitu saja hasil inovasi dan invensinya yang telah menghabiskan waktu dan biaya yang tidak sedikit. Mereka tidak menyadari bahwa seringkali pihak ketiga (para pengusaha baik nasional maupun asing) lebih jeli dalam memanfaatkan hasil inovasi itu untuk kepentingannya.

Untuk mendorong para peneliti menghasilkan teknologi yang berkualitas paten, perlu dilakukan tindakan-tindakan strategis sebagai berikut: a. Meningkatkan upaya sosialisasi UU Paten, sehingga peneliti menyadari betul arti penting perlindungan paten serta memahami prosedur permintaan paten;

b. Mengubah pola pikir para peneliti, di mana sebagian mayoritas mereka hanya berorientasi pada kenaikan pangkat, penyelesaian tugas-tugas proyek penelitian atau penyelesaian jenjang studi, tanpa mengejar target bahwa penelitian itu dapat dipatenkan; dan

c. Penulisan skripsi, tesis dan desertasi, terutama pada Fakultas Teknik dan MIPA seharusnya tidak hanya bertujuan untuk menyelesaikan studi, tetapi diubah menjadi pola penulisan skripsi yang berbentuk deskripsi untuk mengajukan permintaan paten.

Melalui pemberdayaan Lembaga Litbang serta peningkatan gairah para peneliti, diharapkan dapat muncul iklim yang kondusif dalam bidang penemuan dan pengembangan teknologi baru. Sehingga secara tidak langsung akan mendorong peningkatan permintaan paten domestik.

\section{Kebijakan Strategis Direktoriat Jendral (Ditjen) HKI}

Ditjen HKI sebagai pihak yang bertanggung jawab dalam pelaksanaan HKI, memiliki peran yang penting dalam upaya membentuk sistem paten yang wajar, efektif dan realistis yang berguna untuk kepentingan bangsa dan Negara. Berikut beberapa langkah yang dapat dijadikan sebagai kebijakan strategis dalam pelaksanaan paten di Indonesia:

a. Merevisi dan menyempurnakan peraturan perundang-undangan yang telah ada di bidang paten, sesuai dengan kepentingan 
bangsa dan negara dengan tetap memperhatikan konvensi-konvensi internasional.

b. Memasyarakatkan dan mensosialisasikan paten, baik di kalangan industriawan, pengusaha, peneliti, akademiși, maupun di. berbagai lapisan masyarakat lainnya. Program sosialisasi dimaksuidkan untuk -menumbuhkan sikap tanggap terhadap tanda-tanda perubahan dan kesadaran akan pengaruh paten dalam kehidupan sehari-hari. Kegiatan ini dapat dilaksanakan bekerja sama dengan Perguruan tinggi, himpunan pengusaha, LSM dan pihakpihak lainnya, mengingat keberhasilan sistem paten hanya bisa dilakukan bersamasama dengan anggota masyarakat.

c. Menyempumakan administrasi pengelolaan sistem Paten dan meningkatkan pelayanan kepada masyarakat. Sistem paten kontemporer harus memperhitungkan faktor otomasi. Sudah saatnya Kantor paten menerapkan sistem otomasi pengelolaan paten. Sebagaimana Jepang, melalui paperless sistem, permintaan paten dapat dilakukan melalui komputer dan on line ke Kantor Paten Jepang yang berada di Tokyo.

d. Desentralisasi pendaftaran permintaan paten. Permohonan permintaan paten akan semakin mudah apabila desentralisasi pendaftaran dapat direalisasikan. Dengan mengoptimalkan Kanwil departemen Kehakiman dan HAM di semua propinsi untuk dapat menerima permintaan pendaftaran paten, akan memberikan kemudahan pada masyarakat di daerah. Akan tetapi walaupun permintaan pendaftaran paten bisa dilakukan di daerah, akan tetapi mekanisme prosesnya tetap dilakukan di pusat; e. Pembentukan Gugus HKl; Keberadaan organisasi pengelola HKI sangat signifikan bagi kemajuan ekonomi suatu.negara yang ingin membangun perekonomian berbasis pengetahuan. Selain itu, keberadaan organisasi tersebut dapat memberikan arahan bagi peneliti agar penemuanpenemuannya dapat aplikatif terhadap kebutuhan industri dan masyarakat serta memiliki nilai kompetitif.

f. Membantu penegakan hukum di bidang paten; Ditjen HKI telah melakukan koordinasi secara intensif dengan-aparat penegak hukum dan instansi terkait lain, untuk meningkatkan kualitas penegakan hukum di bidang HKI. Untuk itu para penegak hukum perlu meningkatkan pengetahuan dan pemahaman masyarakat di bidang HKI, sehingga dapat terwujud keja sama yang sinergis. Di samping itu, di lingkungan Ditjen HKl juga terdapat tenaga Penyidik Pegawai Negeri Sipil (PPNS) yang bertugas untuk membantu polisi dalam. penegakan hukum HKI.

Demikianlah beberapa hal yang dapat dipertimbangkan untuk mempersiapkan dan atau membentuk sistem HKI yang wajar, efektif dan realistis, sehingga bermanfaat bagi kepentingan bangsa dan negara. Wajar, artinya sistem paten yang dibangun sederhana dan tidak terlalu muluk-muluk. Efektif, artinya hukum paten yang dibangun dapat dilaksanakan secara efektif dan memberikan daya guna bagi kesejahteraan dan kemakmuran masyarakat. Sedangkan relistis, artinya bangsa Indonesia hendak mencapai target yang ideal, namun tetap mempertimbangkan kemampuan dan. fasilitas yang dimiliki. 


\section{Simpulan}

Permasalahan yang dihadapi Indonesia dalam pelaksanaan paten adalah: minimnya permohonan paten domestik "Indonesia, krisis moneter yang berkepanjangan yang menyebabkan banyaknya pelanggaran paten, pandangan masyarakat bahwa paten adalah konsep barat, dan lemahnya penegakan hukum.

Upaya untuk membangun sistem Paten Indonesia yang efektif, wajar dan realistis, dapat dilakukan melalui beberapa instrumen, yaitu: (1) penyempumaan perundang-undangan di bidang paten; (2) pembaharuan sistem pendidikan nasional untuk menyiapkan SDM yang berkualitas, terutama dalam merumuskán sistem pengajaran Matematika dan IPA; (3) membangun budaya masyarakat agar menghargai Hak Kekayaan Intelektual (HKI); (4) merencanakan pola pembangunan teknologi nasional dengan didukung berbagai kebijakan strategis; (5) pemberdayaan lembaga penelitian dan pengembangan (Litbang) serta meningkatkan gairah peneliti; dan (6) penerapan berbagai kebijakan strategis oleh Direktoriat Jendral HKI. $\square$

\section{Daftar Pustaka}

Junus, Emawati."Perubahan atas Undangundang Paten Tahun 1989." Jurnal Hukum Bisnis, Volume 2/1997

Kesowo, Bambang. "Perlindungan Hukum serta Langkah-langkah Pembinaan oleh Pemerintah dalam Bidang Hak Milik Intelektual." Dalam Paten, Pengaturan dan Pelaksanaan. Pusat Pengkajian Hukum. Jakarta. 1993

. "Perlindungan Hak Cipta atas Komputer Program." Sambutan Arahan pada Seminar Hak Cipta dalam Industri Musik dan Perangkat Lunak Komputer serta Penggunaannya di Indonesia. Diselenggarakan oleh Fakultas Hukum Atma Jaya. bekerjasama dengan .P.T. Microsoft Indonesia dan Masyarakat HaKI Indonesia. Yogyakarta. 28 April 1999.

Luthan, Salman. "Instrumen Penegakan Hukum Desain industri, Desain Tata Letak Sirkuit Terpadu, Rahasia Dagang dan Kendalanya." Makalah dalam Seminar Nasional Implementasi Undang-undang Desain Industri, Rahasia Dagang dan Desain Tata Letak Sirkuit Terpadu. Diselenggarakan oleh FH UII bekerja sama dengan Klinik HaKI Jakarta. Yogyakarta, 4 Oktober 2000.

Maulana, Insan Budi. "Penerapan Paten Sejak UU No. 6. Tahun 1989 hingga UU Paten No. 13 Tahun 1997: Pengalaman Indonesia selama ini." Jurnal Hukum. No. 12 Vol. 6. 1999. FH UII Yogyakarta.

Nazif, Amru Hydari. "Paten dan Pengelolaan Penelitian dan Pengembangan." Makalah dalam Seminar Paten dan Teknologi Nuklir dalam Rangka Meningkatkan Daya Saing Bangsa, Badan Tenaga Nuklir Nasional. Jakarta. 18 Agustus 1999

Purba, A. Zein Umar. "Peta Mutakhir HaKI." Makalah dalam Kuliah Umum Fakultas Hukum Universitas Islam Indonesia. Yogyakarta. 31 Maret 2000 . "Penegakan Hukum di Bidang HaKl." Harian Kompas. 22 Mei 2000.

Sinungan, Ansori. "Penegakan Hukum dan Litigasi." Makalah disampaikan dalam 
Training of The Trainer (TOT) Pengelola Gugus HKI Perguruan Tinggi Surabaya dan Semarang. Juli 2000

Subagyo, Tantono. "Perlindungan HaKI di Indonesia." Makalah acuan untuk Sosialisasi HaKI. Tanpa Tahun Direktorat Paten.

Yayasan Klinik HaKI. Kompilasi Undangundang Hak Cipta, Paten Merek dan Terjemahan Konvensi-konvensi di Bidang Hak atas Kekayaan Intelektual (HaKI). Seri A, Citra Aditya Bakti. Bandung. 1999

\section{Kompilasi Undang-undang Hak} Cipta, Paten Merek dan Terjemahan Konvensi-konvensi di Bidang Hak atas Kekayaan Intelektual (HaKI), Seri B. Citra Aditya Bakti. Bandung. 1999.

Yoshiro Sumida. "The Role and Implementation of Patent Law in 21 st Century, The Possible Conflict Between Developed and Developing Countries." Makalah di sampaikan dalam Seminar Nasional. Peranan Hak Cipta, Paten dan Merek dalam Pembangunan Perdagangan dan Industri. Kerja sama FH UII dan
Klinik HaKI Jakarta. Yogyakarta. 9 Desember 1998. Him. 2.

Harian Republika. 9 Januari 1999.

Harian Media Indonesia, 16 Februari 1999

Harian Kompas. 9 Agustus 1999.

Harian Republika. 26 Agustus 1999.

Harian Republika. 14 Januari 2000.

Harian Suara Pembaharuan. 21 Januarh 2000.

Majalah Forum Keadilan, No. 8, 28 Mei 2000 Harian Republik Indonesia. Juni 2000.

Harian Kompas. 22 Nopember 2000.

Harian Kompas. 24 Januari 2001.

Harian Kompas. 11-12 September 2000.

Harian Republika, 3 Januari 2001.

Harian Republika. 16 September 2000.

Peraturan Perundang-Undangan

Agreement on Trade Related Aspects of Intellectual Property Rights (TRIPs Agreement)

Paris Convention for The Protection of Industrial Property (Konvensi Paris)

The Paten Cooperation Treaty (PCT).

Undang-undang Nomor 14 Tahun 2001 tentang Paten. 